rawing from the author's childhood confusion over whether 'prodigal' means profligate or prodigious, this intervention anticipates the politicisation of returning New Zealand citizens. Written during lockdown, the intervention contrasts predictions of a great repatriation and pundits' nationalistic revelling in the country's success at containing the virus with the history of the 'coming home' essay and song. Stephen's argues for a pre-consideration of the emotional states that might be provoked by the returnee. That pre-consideration is aimed at drawing the returnee into the collective, not for the sake of an enlarged spirit of the nation, but for the advancement of Left collective action. 


\section{Welcome Home, Prodigy}

\section{MURDOCH STEPHENS}

Am I the only one who radically misunderstood the story of the prodigal son?' I had read the word 'prodigal' as the favourable adjective for the prodigy, a person with an outsized talent. I had envisioned the story of a young man setting off into the world, pulling himself up by his bootstraps before returning home as a talented and wealthy man. But in researching the parable behind my imaginings, I have learned that the prodigiousness refers to a profligate son-a waster, OK? - and not to a whiz kid.

The moral of my imagined story? I had thought that the parable of the prodigal son was all about not worrying about sons and daughters being away, that they would be fine, and that they would certainly come back and would be better than before. If anything, my version of the story of the prodigal son hinted at the need, without resentment or pride, to make room for outsized talents when they return from abroad, whether that was someone coming back from their OE, or England, finally recognising that Pākehā New

1 I would like to thank Jack Foster (Counterfutures) and Kelly Pendergrast (Antistatic) for their feedback on earlier drafts of this essay. 


\section{Zealanders are their equals. ${ }^{2}$}

The actual story of the prodigal son is much less interesting. It is the classic morality tale of waste and forgiveness, where an overconfident youth ventures into the world and must make his way home with his tail between his legs. It's not a secret. There's a Wikipedia page for it. Heck, it's literally in the Bible that the Gideons literally gave away for free in secondary school.

Aotearoa New Zealand, whether we admit it or not, has always had a vexed relationship with its citizens abroad. The New Zealander insists that it is a rite of passage to explore beyond the South Pacific, but at the same time there is the quiet insistence that there is no place like home. What form does that insistence take? Listen to 'Come Home' by Martin Phillips and the Chills and you can hear it clearly:

Come back to your land

show your face, make a stand

Come home, show you care

the future's here... it's not out there. ${ }^{3}$

The music video contrasts the kind of young New Zealanders in Londonworking in a ritzy pub, but shocked at an elderly beggar-with the purity of an outdoor children's game of hide and seek. The song perfectly captures a natal homing sentimentality and I have more than once used it to make

2 By New Zealander, I chiefly mean Pākehā, but I don't want to entirely delimit the concept. The figure discussed in this essay is a product of Pākehā colonial culture which doesn't mean it is solely derived from Pākehā, but exists in the full exigency of colonial relations. There is no Pākehā without Māori and this is not simply an insincere truism, but a testament to the impossibility of disentangling the two, both in some families and communities, as well as in the infrastructures made on top of the land.

3 Martin Phillips and the Chills (1996) 'Come Home' from the album Sunburnt. Music video available online: https://www.youtube.com/watch?v=x_zbBmETGTY 
a-albeit ironic — clarion call to friends that I miss. ${ }^{4}$ The more I listen the more astounded I am that I can't but enjoy it. I pull enjoyment from the nation-building pathos, perfectly tuned to a small country where the best and brightest (though also the greediest) disappear overseas only to return, like salmon or turtles, to breed so that their children can run free in 100\% Pure New Zealand. This is, or at least was, the sentiment which cloaked the movements of young New Zealanders.

Every Christmas, we have a low-stakes preview of the modern parable of the prodigal son. Friends, especially those in the despair of a northernhemisphere winter, make a journey back to Aotearoa New Zealand to spend the festive season with friends and family. We meet up in bars or at a backyard party. These are times of rekindled friendships and half-hearted plans for what it would be like if we didn't have to go back to Berlin, San Francisco, and London.

Christmas coming-home is also experienced by the New Zealander who has moved from the country or small town to the city. We leave Auckland and Wellington and travel back to see our friends and family, and hope that the joy of seeing them won't be overshadowed by any of the provincial or class differences that have emerged in our absence. For me, this was most clearly felt in the years when I and the others who went to university travelled back to Balclutha for the holidays. While most people were warm, there was a distinct feeling among others that our presence was rubbing their noses in their own lack of movement. It only takes one drunk encounter, or one encounter with a drunk, to see that perhaps not all of our seasonal feelings are of universal love and goodwill to man.

The cry 'come home!' is a sentiment shared by many nations around the world where wages are low and young people often migrate in search

4 One of whom, Kelly Pendergrast, I want to acknowledge as having given feedback to this essay and who pointed to the Front Lawn's (1989) Songs From the Front Lawn as one of the most nostalgic of come home albums. In particular, 'When You Come Back Home' offers what appears to be a song about coming back to Aotearoa New Zealand, but which is far more ambiguous when the lyrics are considered. That misrecognition is perhaps the result of amalgamating the message of that song with that of 'Tomorrow Night' - 'She went to London to find work there / To claim her colonial birthright' — and the theatrical bells-and-whistles of the album. 
of better opportunities. We understand that a country of five million simply can't provide the opportunities afforded by cities of the same size and continents of many, many more. And yet we build up Aotearoa New Zealand as the place to raise a family, a safe yet relatively developed oasis in a world prone to chaos. Holding these contradictions together is a difficult act, but is performed by many countries: we are Schrödinger's nations, simultaneously losing the best young minds, while also being the best place to exist in the world-Godzone.

The ambivalent story of the prodigal son, it doesn't matter if they're a waster or a jewel, is an interesting one for the year of Covid-19, as it foreshadows the psychosocial reception of the child gone into the world and forced to come home. ${ }^{5}$ According to Minister of Foreign Affairs Winston Peters, by the end of April, 80,000 New Zealanders have returned home. ${ }^{6}$ Covid-19 promises to catalyse a great migratory reset, a homing of the transitory back to lands of surer citizenship and rights. Jobless New Zealanders in Australia are suddenly confronted with the reality of their status as non-citizens. Others, who are without permanent roles or foreign lovers, weigh up the costs and benefits of coming home. We've seen your Instagram posts, your blogs, your Facebook stories - and with the expected economic recession, there will be more, new pulls for New Zealanders overseas to return.

From ambivalent impulses (welcome and repulsion, reflection and amnesia, pride and shame) the country has forged a genre of reflective writings that we might call the 'Coming Home essay'. The Coming Home essay is a bittersweet meditation on the trials of returning, but also incorporates the reflections on New Zealand from outside; think Bill

5 As a child, I also misread ambivalent to mean uncaring or disinterested. These days I have made something of an overcorrection in my use of the word, treating it as meaning radically undecidable in the Derridean sense, rather than simply meaning that one contains mixed or contradictory views about something.

6 Although these are not all returnees; many, if not most, will be holidaymakers who have cut their trips short. 
Pearson's 'Fretful Sleepers'. ${ }^{7}$ Nigel Cox's 'Before I Went Blind' is a triumph of the genre, beginning with lines which might seem apt for those New Zealanders returning with assistance from MFAT: 'So where do you start: Winston Peters? I don't think so-but, coming back, your eyes fall on such things and you think: You, still alive! I want him gone by lunchtime'. ${ }^{8}$ And yes, we are in the run up to another election.

Cox's essay richly registers the minutiae of returning home, but does so, curiously, via the second person. The second person feels deferential, when he is really referring to himself: 'But you're pleased to be back. That's what you keep telling yourself-you've thrown the dice, there's no turning back, so, of course you're pleased to be back. But in fact you are'. The circumstances of the Coming Home essay are never the same. Some are, like Cox's, insistent that they chose to return: there was even a permanent contract that was forsaken. Others might also insist that the time was right for them to return, though if you scratch a little deeper it is the end of a visa or relationship that contributes to making the time right. Others must boomerang back to this country to work through the rites of natal homing and baby-boomer funerals; we might forget inevitabilities (and not just Winston Peters) while at Berghain, but they don't forget about us.

Even those who have correctly read the story of the prodigal son may have missed the most apt part of the parable for a time when many New Zealanders are returning. We should not focus on the relationships of parent and child as a way to emphasise universal love. ${ }^{10}$ We should focus, instead, on the least-considered character in the parable: the older brother who never left home. While the younger brother hassled his Dad for the

7 Bill Pearson, 'Fretful Sleepers: A Sketch of New Zealand Behaviour and its Implication for the Artist,' in Fretful Sleepers and Other Essays (Auckland: Hienemann Publishers, 1974).

8 Nigel Cox, 'Before I Went Blind,' Sport 33 (Wellington: Victoria University Press, 2005).

9 Cox, 'Before I Went Blind,' 171.

10 This is a leftist journal, after all: universal love is taken as read ;) 
inheritance and then, one assumes, blew it on Es and whizz in London, the older brother remained at home, working on the farm, digging into the swappa crates at the weekend, and just being a good Kiwi. That's you. Or someone like you. You're the older brother. The one who never really left.

Let's pause for a second to dig back into the parable. In the original parable, the older brother resents the younger brother and presents this case to his father. He complains that the younger brother receives love and attention as a reward for his bad behaviour, while the law-abiding older brother doesn't even get a baby goat to slaughter with his mates. And the Dad tells him to chill out; in fact, the line, 'I once was lost, but now I'm found' from 'Amazing Grace' riffs off the father's reply to the older brother that the younger son was like a dead person, now alive-and this miracle of the return is what requires the celebration.

How does the older brother take this argument? Luke 15 ends there and, in the following chapter on 'The Parable of the Shrewd Manager'; we're offered no further guidance.

Covid-19 has already led to the return of many of our prodigies. More will return, they say, when the global recession kicks in. There will be sons and daughters, mates and lovers, friends and rivals. We will see someone on Karangahape Rd, or Cuba St, or George St, whom we hadn't seen in years. We may not have thought of them when they were away, but there they will be. They might be hired in our workplaces, as bosses or colleagues. They might join our community choirs, our Jobseeker seminars at WINZ, protests for Ihumātao, or our bell hooks reading groups.

How are we to comport ourselves when faced with the returnees? With close friends it is easy. I can easily count a handful whom I would welcome back with unconditional love. But what of those others, those a little more distant? I'm reminded of how petty some can be when I think of the arguments from professional associations against accepting their fellow Jewish professionals as refugees before and during World War Two. ${ }^{11}$ Those New Zealanders would rather have had their professional competitors stay

11 Ann Beaglehole, A Small Price to Pay: Refugees from Hitler in New Zealand, 1936-46 (Wellington: Bridget Williams Books, 1988). 
in Europe and take on Hitler than crowd out the job market in Aotearoa New Zealand. There's no reason to think that all would happily welcome back citizens if it meant more competition for scarce work.

But surely we'd welcome them all back? Isn't it our patriotic duty to keep the borders open for every citizen (and permanent resident) to return? During the first weeks of the Covid-19 lockdown there have been many reports of an increase in New Zealand patriotism, from a University of Auckland study to a John Armstrong opinion piece noting the flagrant use of patriotism in television advertisements by large companies. ${ }^{12}$ Even a confessed leftist, Morgan Godfery, writing in The Guardian, feels the burn:

I feel like a New Zealand patriot.

I'm hardly a nationalist, and as a leftist, my dominant mode is bitter defeat, expecting it in almost every circumstance. But as the country prepares to move from alert level four to alert level three - meaning from a major lockdown to a moderate lockdown - patriotism seems irresistible. ${ }^{13}$

These belches of patriotism are not the only disturbance in the air; they are matched by the flatulence of racism, which can be seen across the 252 reports of racial harassment of people perceived to be other to New Zealand, mostly Chinese. ${ }^{14}$ Paul Spoonley had noted that there is likely to be election year hostility to non-Pākehā based on rising unemployment and electoral populism. ${ }^{15}$

12 John Armstrong, 'John Armstrong's opinion: Why New Zealand has to remain in lockdown,' 1 News, 18 April 2020; Lee Kenny, 'Coronavirus: Has the lockdown changed you? Volunteers needed for psych analysis,' Stuff, 22 April 2020.

13 Morgan Godfery, 'A strict Covid-19 lockdown gave New Zealand a key ingredient to recover - solidarity,' The Guardian, 20 April 2020.

14 Donna Lee-Biddle, 'Coronavirus: Asian parents remove child from school as Covid-19 racism spikes,' Stuff, 4 May 2020; Torika Tokalau, 'Coronavirus: Auckland gym owner says her anti-China comments "not related to racism,"' Stuff, 30 March 2020; Simon Collins, 'Covid 19 coronavirus: Woman challenges anti-Chinese gesture in Mission Bay,' NZ Herald, 26 March 2020.

15 Godfery, 'A strict Covid-19 lockdown.' 
It is in this context of patriotism and xenophobia that we need to consider how we welcome back the New Zealand citizen who has been living abroad. The elder brother in the tale of the prodigal son might be just as resentful of the return of the son-who-is-a-prodigy as the profligate-son. Their resentment, as per my intervention in Counterfutures 8, is based on having a negative attitude towards someone whom they perceive as better than themselves. ${ }^{16}$ In that intervention, I argued that the negative attitude (see the far right column in Table 1) is not the damaging aspect in that relationship_especially from a left-wing view. Rather, seeing the other as better than me is the problem and needs reappraisal. I counselled moving from resentment and pity towards hatred.

\begin{tabular}{|l|l|l|l|l|}
\hline \multicolumn{2}{|c|}{} & \multicolumn{2}{l|}{ Type of feeling } \\
\cline { 2 - 5 } & \multicolumn{2}{|l|}{ Positive } & Moderate & Negative \\
\hline $\begin{array}{l}\text { Relation } \\
\text { of other to } \\
\text { the self }\end{array}$ & Better than I & Admiration & Respect & Resentment \\
\cline { 2 - 5 } & Equal to I & Affection & Esteem & Hate \\
\cline { 2 - 5 } & Worse than I & Acceptance & Tolerance & Pity \\
\hline
\end{tabular}

Table 1. Emotional relations to valuing another.

For this intervention, I take a more brotherly approach and suggest the Left would do best in abandoning the negativity of the elder brother. We ought to take on the moderate spirit of the father. In the schema of Table 1, this means, at the least, moving from the negative column to the moderate column: resentment becomes respect, hate becomes esteem, pity becomes tolerance. The father in the parable of the prodigal son prepares a feast for the returning son as a way to show that they are welcome, but that does not mean that the son is wholly redeemed or rehabilitated. Similarly, welcoming the prodigious son back requires esteem, if not respect; if not, further to these, the admiration and affection that we might reserve for

16 Murdoch Stephens, 'Pity, Hate, Resentment and the Left,' Counterfutures 8 (2019): 127-139. 
close friends and the odd celebrity returning from Los Angeles with their tail between their legs.

But why can't we just hate those who have been forced to return to New Zealand? For starters, even when I counselled for hate over pity and resentment it wasn't for all relations to be of hate. Politically, though — and it always ends up there- esteeming or respecting our returnees is a strategic counter to both overzealous patriotism and the potential for a misplaced resentment of those who return. These emotions, affection and esteem, are the basis of solidarity, which is, if we agree with Nancy Fraser, the key to a rebirth of the Left that does not rely on the othering of patriotism. ${ }^{17}$

We should be like the father and seek out those who have returned and make sure that the country they come home to is still a place that values fairness (at least at the mythological level) over less communal values. We ought to work with them and their skills in building a stronger left-wing response to both the challenges of Covid-19 and the underlying threats from an embedded neoliberalism and capture of the parliamentary left by pragmatic centrists. We should encourage their writings, their Coming Home essays, their songs and art, and, above all, their criticisms of us and New Zealand.

In bolstering the Left, these prodigal returnees will also be ambassadors for cosmopolitanism. Cosmopolitanism is likely to have a tough run in the coming years, when unemployment runs high and neoliberal excesses come to be treated as synonymous with globalisation. But cosmopolitanism will be necessary to counter a milquetoast nationalist leftism, such as that which recently throttled the once-in-a-lifetime genuine-left Labour Party of the United Kingdom into electoral failure. Our prodigies will be our best defence against those who insist that a little nationalism isn't such a danger as long as it offers a stronger union, or a higher minimum wage.

Beyond the expected xenophilia of the returnees, we might also take the chance to think big. All those coming-home dreams put into practice at once: bolstering union and political memberships, dismantling the rentier's fancies and the splintered fetishism of the housing market, tino rangatiratanga, and a Left worth living.

17 Nancy Fraser, The Old is Dying and the New Cannot Be Born (London: Verso, 2019). 